\title{
Deoxyribonucleic Acid Base Composition and Taxonomy of Thiobacilli and some Nitrifying Bacteria
}

\author{
By J. F. JACKSON, D. J. W. MORIARTY AND D. J. D. NICHOLAS \\ Department of Agricultural Biochemistry, Waite Agricultural Research \\ Institute, The University of Adelaide, South Australia
}

(Accepted for publication II March I968)

\begin{abstract}
SUMMARY
The DNA base composition of 14 authentic strains of the genus Thiobacillus, determined by caesium chloride density gradient centrifugation, was found to vary from $5 \mathrm{I}$ to 68 mole $\%$ guanine + cytosine $(\mathrm{G}+\mathrm{C})$. The mole $\%$ $\mathrm{G}+\mathrm{C}$ values for the various species are as follows: $T$. thiooxidans and $T$. concretivorus 5I-52, $T$. neopolitanus and $T$. ferrooxidans 56-57, and $T$. thioparus, $T$. thiocyanoxidans, $T$. denitrificans, $T$. novellus and $T$. trautweinii 62-68. Another group of chemoautotrophic bacteria, the nitrifiers Nitrosomonas europaea and Nitrobacter agilis, were found to have a $\mathrm{G}+\mathrm{C}$ content of 52 and $65 \%$, respectively. The results are compared with other types of taxonomic studies made with these and related bacteria.
\end{abstract}

\section{INTRODUCTION}

Thiobacilli are Gram-negative, non-sporulating, rod-shaped bacteria, usually found in soils and in marine and fresh water (Vishniac \& Santer, 1957; Trudinger, 1967a). It might be assumed from their common function in oxidizing certain inorganic sulphurcontaining compounds and in utilizing carbon dioxide as sole carbon source, that species within the genus Thiobacillus are closely related genetically. These physiological criteria may not however be sufficient in themselves to support this conclusion, since many different types of micro-organisms fix carbon dioxide, e.g. the nitrifying bacteria (Alexander, 196I), and some heterotrophic organisms readily oxidize sulphur compounds (Trudinger, $1967 \mathrm{~b}$ ).

The taxonomy of thiobacilli has recently been studied by Hutchinson, Johnstone \& White (1965, I966, 1967). They used a multivariate analysis (Beers \& Lockhart, 1962; Sneath, I957) to demonstrate that the genus consists of well-defined species and an unusual absence of intermediate forms. This method, however, has the disadvantage that it does not analyse directly the relationships between all the species of the genus Thiobacillus. This is because some of these species are aerobic, others anaerobic, some acidophilic, whereas others prefer more neutral $\mathrm{pH}$ conditions. Moreover, although this numerical analysis was based upon Ioo or so phenotypic properties, it accounts for only a small proportion of the bacterial genome. Another way of examining the interrelationships between a group of micro-organisms is to compare the over-all base composition of their DNA complement. It has been applied with success to the pseudomonads (Mandel, 1966) and other bacteria. A list of the DNA base compositions of some bacteria was given by Hill (1966). For bacterial species to be closely related, it is necessary that their DNA should have a similar over-all base composition. 
This method has the advantage over multivariate analysis in that a comparison of the thiobacilli can be made directly on the basis of the whole genome. We have extracted DNA from various species of thiobacilli and from some nitrifying bacteria, and examined the over-all base composition of each by $\mathrm{CsCl}$ density gradient centrifugation.

\section{METHODS}

Organisms. Strains of Thiobacillus thiooxidans, $T$. concretivorus, $T$. novellus, $T$. trautweinii and $T$. ferrooxidans were supplied by the National Collection of Industrial Bacteria (NCIB), Torrey Research Station, Aberdeen, Scotland (see Table I). Strains I P and 2 P, originally from C. P. Parker, Melbourne, Australia, were procured from Dr R. Swaby, C.S.I.R.O., Division of Soils, Adelaide, South Australia. Samples of $T$. neopolitanus and $T$. denitrificans were obtained from Dr P. A. Trudinger (BaasBecking Laboratories, Canberra). Dr I. M. H. Aleem (Research Institute for Advanced Studies, Baltimore, Maryland, U.S.A.), supplied strains of Ferrobacillus ferrooxidans (hereafter referred to as $T$. ferrooxidans; for discussion of the nomenclature see Hutchinson et al. 1966) and Nitrobacter agilis. The Nitrosomonas europaea strain used was obtained from Dr Jane Meiklejohn (Rothamsted Experimental Station, England).

Growth conditions. All the bacteria used here were grown in media listed below, either in flasks on a gyrotary shaker where the total volume was I l. or less, or in carboys up to $40 \mathrm{I}$. capacity. In the latter case sterile air was forced through the medium by using sintered glass aerators attached to a compressed air line. The culture media were either sterilized at $12 \mathrm{I}^{\circ}$ for $45 \mathrm{~min}$. or, when more than $\mathrm{I} 01$. were used, the medium was filtered through a Millipore filter assembly (diam. $142 \mathrm{~mm}$., pore size $0.22 \mu$, with prefilter). The larger carboys were sterilized by placing a specially constructed ultraviolet lamp inside them for several hours. The energy output of this lamp was 95 microwatts $/ \mathrm{cm} .^{2}$ at $\mathrm{I} \mathrm{m}$. distance, measured at $253.7 \mathrm{~m} \mu$.

A minimum of $10 \%(\mathrm{v} / \mathrm{v})$ inoculum was used to seed the cultures in all these experiments. All cultures were grown at $30^{\circ}$ and the growth rate followed by counting the bacteria periodically in a haemacytometer. A generation time of not less than $14 \mathrm{hr}$ was recorded for these chemoautotrophic bacteria.

Media. Thiobacillus thioparus, $T$. novellus and $T$. trautweinii were grown in the culture medium containing thiosulphate as described by Vishniac \& Santer (1957) for $T$. thioparus; this medium was initially at $\mathrm{pH} 7$. Growth of $T$. thioparus and $T$. novellus decreased the $\mathrm{pH}$ value of the medium, while that of $T$. trautweinii increased it. Thiobacillus thiooxidans and $T$. concretivorus were grown in a medium similar to that for $T$. thioparus, except that the initial $\mathrm{pH}$ value was made to 5.6 by substituting the following amounts of phosphate buffer (g./1. medium): $\mathrm{K}_{2} \mathrm{HPO}_{4}, 0.5$ and $\mathrm{KH}_{2} \mathrm{PO}_{4}, 7 \cdot 5$.

The two strains of Thiobacillus ferrooxidans were grown in a medium containing (g.): $\left(\mathrm{NH}_{4}\right)_{2} \mathrm{SO}_{4}, 3 ; \mathrm{KCl}, 0.1 ; \mathrm{MgSO}_{4} .7 \mathrm{H}_{2} \mathrm{O}, 0.5 ; \mathrm{Ca}\left(\mathrm{NO}_{3}\right)_{2}, 0.01 ; \mathrm{KH}_{2} \mathrm{PO}_{4}, 0.2$; in glassdistilled water, $700 \mathrm{ml}$. To this solution, which was autoclaved separately, was added $45 \mathrm{~g}$. $\mathrm{FeSO}_{4} \cdot 7 \mathrm{H}_{2} \mathrm{O}$ and $\mathrm{I} \mathrm{ml}$. $10 \mathrm{~N}-\mathrm{H}_{2} \mathrm{SO}_{4}$ dispensed in $300 \mathrm{ml}$. distilled water. The medium was then at $\mathrm{pH} 2 \cdot 7$.

The medium for Nitrosomonas europaea contained (g./1. distilled water): $\left(\mathrm{NH}_{4}\right)_{2} \mathrm{SO}_{4}$, $4 ; \mathrm{KH}_{2} \mathrm{PO}_{4}, 0.5$; and (mg./1.) $\mathrm{MgSO}_{4} \cdot 7 \mathrm{H}_{2} \mathrm{O}, 50 ; \mathrm{CaCl}_{2} .2 \mathrm{H}_{2} \mathrm{O}, 4$; chelated iron, $0 . \mathrm{I}$ 
(Nicholas \& Rao, 1964). Phenol red was added as internal indicator and the medium adjusted with $20 \%(\mathrm{w} / \mathrm{v}) \mathrm{K}_{2} \mathrm{CO}_{3}$ solution to $\mathrm{pH} 8$.

Nitrobacter agilis was grown in the following medium (g./l.): $\mathrm{KNO}_{2}, 0.3 ; \mathrm{K}_{2} \mathrm{HPO}_{4}$, $0.175 ; \mathrm{MgSO}_{4} .7 \mathrm{H}_{2} \mathrm{O}, 0.175 ; \mathrm{NaCl}, 0.1 ; \mathrm{KHCO}_{3}, 0.5 ;$ and chelated iron, $0 . \mathrm{I}$. A sterile I0 $\%(\mathrm{w} / \mathrm{v})$ solution of $\mathrm{KNO}_{2}$ was added automatically to maintain a value of $200 \mathrm{mg} . / 1$. during growth.

Isolation of DNA. About $\mathrm{I}-4 \mathrm{~g}$. wet weight of bacteria was collected from Io to 401 . of culture by continuous flow centrifugation in a Sorvall RC-2 refrigerated unit. The bacteria were stored at $-17^{\circ}$. The procedure of Marmur (196I) for Gramnegative bacteria was used to prepare the DNA, except where otherwise stated in the results. The DNA preparations were characterized by u.v. absorption, and deoxypentose, pentose and organic phosphate determinations. The preparations were stored in $0.05 \mathrm{M}$-tris $\mathrm{HCl}(\mathrm{pH} 8)$ at $-17^{\circ}$.

Determination of DNA base composition. The base composition of the various samples was determined by $\mathrm{CsCl}$ density gradient centrifugation as follows: $\mathrm{CsCl}$ $(\mathrm{I} \cdot \mathrm{I} 28 \mathrm{~g}$.) was dissolved in $0.86 \mathrm{ml}$. $0.0 \mathrm{I} \mathrm{M}$-tris $\mathrm{HCl}$ buffer $(\mathrm{pH} 8)$ containing approximately $5 \mathrm{~m} \mu$ moles of the DNA to be tested and $5 \mathrm{~m} \mu$ moles of a DNA from either calf thymus or Escherichia coli as a reference. $E$. coli DNA was prepared from $E$. coli B cells according to the method of Marmur (196I), and the DNA from calf thymus purified following the procedure of Kay, Simmons \& Downce (I952). Optical grade $\mathrm{CsCl}$ was obtained from Stanley $\mathrm{H}$. Cohen (Yonkers, New York). The refractive index of the solution containing the DNA samples was measured to check the final $\mathrm{CsCl}$ concentration. This solution was then used for density gradient centrifugation in a Spinco Model E analytical ultracentrifuge fitted with a titanium rotor. The u.v. photographs taken after $\mathrm{I} 7 \mathrm{hr}$. at $44,770 \mathrm{rev} . / \mathrm{min}$. and $25^{\circ}$, were used to determine the density of the unknown DNA. For this purpose, tracings were made on a Beckman Analytical recording densitometer equipped with a film attachment. The buoyant densities of the reference DNA samples were taken as $\mathrm{I} \cdot 710 \mathrm{~g} . \mathrm{cm}^{-3}$ for $E$. coli DNA and $\mathrm{r} \cdot 699 \mathrm{~g} . \mathrm{cm} \cdot{ }^{-3}$ for calf thymus DNA, and the base composition of the unknown sample calculated as described by Schildkraut, Marmur \& Doty (1962), using the equation $\rho=\mathrm{I} \cdot 660+0.098(\mathrm{GC})$, where $\rho=$ buoyant density.

\section{RESULTS AND DISCUSSION}

\section{DNA isolation}

Since most of the chemoautotrophic bacteria investigated are Gram-negative, they were easily lysed by detergent as described by Marmur (I96I). There were, however, two exceptions, Thiobacillus concretivorus and $T$. ferrooxidans.

Thiobacillus concretivorus, strain IP. Unlike strains 2 P and 95I4, strain I P did not lyse with sodium lauryl sulphate. To prepare a DNA sample from this strain, it was necessary to break the bacteria with aqueous phenol mixtures. Bacteria (2 g. wet wt) were suspended in $20 \mathrm{ml} .0 .05 \mathrm{M}$-tris $\mathrm{HCl}(\mathrm{pH} 8)$ containing $2 \%(\mathrm{w} / \mathrm{v})$ sodium lauryl sulphate, then shaken with $20 \mathrm{ml}$. phenol saturated with aqueous $\mathrm{M}$-tris $\mathrm{HCl}(\mathrm{pH} 8)$. After centrifugation at $6000 \mathrm{~g}$ for $10 \mathrm{~min}$., the upper aqueous layer was collected and the DNA precipitated from it with 2 vol. of ethanol. The method of Marmur (I96I) was then followed to achieve further purification. Despite the different extraction technique used, the base composition of the DNA prepared from strain $T$. concretivorus I P was the same as that for strains $2 \mathrm{P}$ and 9514 (see Table I). 
Thiobacillus ferrooxidans. In these experiments, $T$. ferrooxidans organisms were not lysed by detergent alone, lysozyme followed by detergent, grinding with glass powder (500-mesh), or even by shaking with aqueous phenol mixtures at $20^{\circ}$ or $60^{\circ}$. A DNA preparation was obtained by suspending $0.6 \mathrm{~g}$. wet wt bacteria in a mixture containing $2.5 \mathrm{ml}$. of $\mathrm{O} . \mathrm{I} \mathrm{M}$-tris $\mathrm{HCl}(\mathrm{pH} 8)$ and $2.5 \mathrm{ml}$. phenol previously saturated with aqueous $\mathrm{M}$-tris $\mathrm{HCl}(\mathrm{pH} 8)$. This suspension was given ultrasonic treatment for $\mathrm{I}$ min. at $0^{\circ}$ with an M.S.E. model 60 W. ultrasonic disintegrator ( $20 \mathrm{kcyc} . / \mathrm{sec}$.). After centrifugation at $6000 \mathrm{~g}$ for Io min. the upper aqueous layer was removed and the DNA precipitated with 2 vol. of ethanol. The purification was then continued as described by Marmur (196I). This method, however, did not always yield DNA. It is possible that small amounts of ferric oxide and perhaps other compounds of iron in the bacteria

Table I. DNA base compositions of Thiobacillus species

\begin{tabular}{|c|c|c|c|}
\hline Species & Strain & $\begin{array}{l}\text { Buoyant } \\
\text { density } \\
\left(\mathrm{g} . \mathrm{cm} .^{-3}\right)\end{array}$ & $\begin{array}{c}\text { Base } \\
\text { composition } \\
\text { (mole \% } \\
G+C)\end{array}$ \\
\hline T. trautweinii & NCIB 9549 & $I \cdot 725$ & 66 \\
\hline T. novellus & $\begin{array}{l}\text { NCIB } 9113 \\
\text { NCIB } 8093\end{array}$ & $\begin{array}{l}I \cdot 727 \\
I \cdot 725\end{array}$ & $\begin{array}{l}68 \\
66\end{array}$ \\
\hline T. denitrificans & Baas-Becking (Trudinger) & $I \cdot 723$ & 64 \\
\hline T. thioparus & $\begin{array}{l}\text { NCIB } 8349 \\
\text { NCIB } 8370\end{array}$ & $\begin{array}{l}I \cdot 725 \\
I \cdot 72 I\end{array}$ & $\begin{array}{l}66 \\
62\end{array}$ \\
\hline T. thiocyanoxidans & NCIB 5177 & $1 \cdot 722$ & 63 \\
\hline T. neopolitanus & Baas-Becking (Trudinger) & $1 \cdot 715$ & 56 \\
\hline T. ferrooxidans & (Aleem) & $I \cdot 716$ & 57 \\
\hline$T$, thiooxidans & $\begin{array}{l}\text { NCIB } 9112 \\
\text { NCIB } 8085\end{array}$ & $\begin{array}{l}1.711 \\
1.711\end{array}$ & $\begin{array}{l}52 \\
52\end{array}$ \\
\hline T. concretivorus & $\begin{array}{l}\text { NCIB } 9514 \\
\text { IP } \\
2 P\end{array}$ & $\begin{array}{l}1 \cdot 710 \\
1.710 \\
1.711\end{array}$ & $\begin{array}{l}51 \\
51 \\
52\end{array}$ \\
\hline
\end{tabular}

complexed with some or all of the DNA and RNA, rendering them insoluble during cell breakage. Ferric ions are known to precipitate DNA (Hammerstein, 1924). Although differential centrifugation removed some of the free ferric compounds from the whole bacteria, this did not improve the extraction of the nucleic acids, presumably because of the iron compounds within the cells (Dugan \& Lundgren, 1965). Addition of Na-EDTA during lysis was without effect. After several attempts, DNA was isolated from Aleem's strain of $T$. ferrooxidans but as yet none has been obtained from strain NCIB9490. The DNA preparation from Aleem's strain gave a band much broader than usual in the $\mathrm{CsCl}$ density gradient, indicating a relatively low molecular weight. This was probably a result of shearing forces operating during the ultrasonic treatment.

\section{DNA base composition of Thiobacillus species}

The buoyant densities of $\mathrm{CsCl}$ solutions and the corresponding base compositions of DNA preparations from the Thiobacillus species are listed in Table I. In general, the value for buoyant density is reliable to $\pm 0.00 \mathrm{I} \mathrm{g.} \mathrm{cm} .{ }^{-3}$, and so the probable error in base composition as determined by this method is $\pm \mathrm{I} \% \mathrm{G}+\mathrm{C}$ (Schildkraut, Marmur \& Doty, 1962). 
The DNA base composition for all the members of the genus Thiobacillus tested were in the range $5 \mathrm{I}-68$ mole $\% \mathrm{G}+\mathrm{C}$. Further subdivision into three groups can be made, based on this parameter. Thus one group with $62-68 \% \mathrm{G}+\mathrm{C}$ included T. trautweinii (the only facultative autotroph in the genus), $T$. novellus, $T$. denitrificans, $T$. thioparus and $T$. thiocyanoxidans. These organisms thus have $\mathrm{G}+\mathrm{C}$ content similar to some of the pseudomonads (Hill, 1966), in particular Pseudomonas aeruginosa (64-68\%) and Pseudomonas fuorescens (60-64.5\%). Since these heterotrophs also oxidize certain inorganic sulphur compounds (Trudinger, $1967 \mathrm{~b}$ ), it would be of interest to study further their relationship to the genus Thiobacillus.

Another group which included Thiobacillus thiooxidans and $T$. concretivorus showed a base composition of $5 \mathrm{I}-52 \% \mathrm{G}+\mathrm{C}$, and was therefore clearly separated from the rest of the genus. Thiobacillus neopolitanus and $T$. ferrooxidans were distinct from both these groups since the base composition was intermediate $(56-57 \% \mathrm{G}+\mathrm{C})$. This does not necessarily mean that these two bacteria are closely related to each other, but it does suggest that they are not closely allied to the other members of the genus.

The DNA preparation from Thiobacillus thiocyanoxidans NCIB 5I77, by $\mathrm{CsCl}$ density gradient centrifugation, gave a second minor band. This band made up to $10-20 \%$ of the total DNA present, and had a buoyant density of $1 \cdot 718 \mathrm{~g} . \mathrm{cm} \cdot .^{-3}$, and a $\mathrm{G}+\mathrm{C}$ content of $59 \%$. This observation illustrates an advantage of the buoyant density method over other teehniques for base composition determination, since it shows that all the preparations investigated in the present work with the exception of $T$. thiocyanoxidans NCIB 5177, had only one species of DNA present with respect to over-all base composition. We have no proof at present that this minor band is not derived from a second or contaminating organism in the $T$. thiocyanoxidans culture. This minor band, like the major component, is shifted by $0.013 \mathrm{~g} . / \mathrm{cm} .^{-3}$ to a higher buoyant density in $\mathrm{CsCl}$ solutions following heat denaturation, and so is double stranded. It may be of interest that Pseudomonas stutzeri, another organism capable of oxidising inorganic sulphur compounds, was found by Mandel (1966) to have a minor 'satellite' DNA component.

Brief reports of the DNA base composition of two Thiobacillus species have previously been recorded. Marmur, Falkow \& Mandel (I963) quote a value of 68-70 mole $\% \mathrm{G}+\mathrm{C}$ for $T$. thioparus (method unspecified); this is reasonably close to the figure reported here. Bohacek, Kocur \& Martinec (I965) give a value of 58-59\% G+C for $T$. novellus which is different from our measurements made on two authentic strains.

\section{Comparison with a multivariate analysis of Thiobacillus species}

Hutchinson et al. (1965, 1966, 1967) were able to recognize six groups within the genus Thiobacillus by means of a multivariate analysis. The order of similarity (S values) of these groups, as indicated by this numerical analysis, is compared in Table 2 with data from the over-all DNA base composition. Where $\mathrm{S}$ values can be compared directly (groups 0-4), the order tends to follow that of the base composition.

To make this comparison, $T$. concretivorus is included in group 5 with $T$. thiooxidans, whereas $T$. thiocyanoxidans is placed in group 3 with $T$. thioparus. Hutchinson et al. (1965) stated that there was not sufficient difference in $\mathrm{S}$ values between $T$. thiocyanoxidans and $T$. thioparus, or between $T$. concretivorus and $T$. thiooxidans, to justify subdividing either group 3 or group 5 . The results for DNA base composition 
reported here tend to support this view (see Table I). Another point of agreement between the two investigations is the unequivocal demonstration of the difference between $T$. thioparus and $T$. neopolitanus (Table 2). Some doubt had been expressed earlier about this (see discussion by Hutchinson et al. 1965).

Table 2. Comparison of multivariate analysis and over-al! DNA base composition

\begin{tabular}{|c|c|c|c|c|}
\hline Species & $\begin{array}{l}\text { Group no. } \\
\text { (multi- } \\
\text { variate } \\
\text { analysis) }\end{array}$ & $\begin{array}{l}\text { Range of } \\
S \text { values* }\end{array}$ & $\begin{array}{c}\text { Mean } \\
\text { S value* }\end{array}$ & $\begin{array}{l}\text { DNA base } \\
\text { composition } \\
\text { (mole } \% \\
G+C)\end{array}$ \\
\hline T. trautweinit & 0 & $94-63$ & 71 & 66 \\
\hline$T$. novellus & I & $49-46$ & 47 & $66-68$ \\
\hline$T$. denitrificans & 2 & - & - & 64 \\
\hline T. thioparus $\dagger$ & 3 & $45^{-24}$ & 35 & $62-66$ \\
\hline$T$. neopolitanus & 4 & $37-18$ & 27 & 56 \\
\hline T. ferrooxidans & $\begin{array}{l}4 \\
6\end{array}$ & - & -1 & 57 \\
\hline T. thiooxidans & 5 & - & - & $51-52$ \\
\hline
\end{tabular}

* The $S$ values listed are taken from Table 4 of Hutchinson et al. (1965). They refer to $S$ values of the various strains, all with respect to the $3 F$ strain of $T$. trautweinii. This particular strain was chosen since it represents an extreme case, and so enables all the species to be arranged in an order of similarity. $T$. denitrificans is listed between $T$. novellus and $T$. thioparus by reason of the results of aerobic tests made by Hutchinson et al. (1967).

+ Includes $T$. thiocyanoxidans.

$\ddagger$ Includes $T$. concretivorus.

Table 3. DNA base composition of Nitrobacter agilis and Nitrosomonas europaea

\begin{tabular}{|c|c|c|c|}
\hline Bacterium & $\begin{array}{l}\text { Energy yielding } \\
\text { reaction }\end{array}$ & $\begin{array}{c}\text { Buoyant } \\
\text { density } \\
\left(\mathrm{g} . \mathrm{cm}^{-3}\right)\end{array}$ & $\begin{array}{l}\text { DNA base } \\
\text { composition } \\
\text { (mole } \% \\
\mathrm{G}+\mathrm{C} \text { ) }\end{array}$ \\
\hline N. agilis & $\mathrm{NO}_{2}^{-} \rightarrow \mathrm{NO}_{3}^{-}$ & $1 \cdot 724$ & 65 \\
\hline N. europaea & $\mathrm{NH}_{4}^{+} \rightarrow \mathrm{NO}_{2}^{-}$ & I.7II & 52 \\
\hline
\end{tabular}

Starkey (1935) and Baalsrud (1954) suggested that Thiobacillus trautweinii be excluded from the genus Thiobacillus. The results of Hutchinson et al. (1965) support this view, although they state that their investigations were not designed to test this point specifically. Although it has a $\mathrm{G}+\mathrm{C}$ content within the range found for other species classified in the genus, the present DNA base composition studies carried out on this organism do not allow a positive decision to be made on this point.

As mentioned in the Introduction, a DNA base composition study enables a comparison to be made between all members of the genus, regardless of cultural conditions. Thus, as well as substantiating the suggestion of Hutchinson et al. (1965) that Thiobacillus thiooxidans and $T$. ferrooxidans are clearly separable, the present work goes further and establishes that $T$. thiooxidans (including $T$. concretivorus) are not closely related to the rest of the genus.

\section{DNA base composition of the nitrifying bacteria}

Although Nitrosomonas europaea and Nitrobacter agilis are both nitrifying bacteria (Alexander, 196I), they are quite distinct from each other since they utilize different inorganic nitrogen compounds, and have a distinctive cell ultrastructure (Murray, 
1963). This is also confirmed by their widely different DNA base composition (Table 3). The value obtained here for $N$. europaea is similar to that quoted by Marmur et al. (1963) for a 'Nitrosomonas sp.' $(54-56 \% \mathrm{G}+\mathrm{C})$, and by Anderson, Pramer \& Davis (1965) who found $50-5 \mathrm{I} \% \mathrm{G}+\mathrm{C}$ for $N$. europaea. The DNA samples from the nitrifying bacteria have a $\mathrm{G}+\mathrm{C}$ content within the range found for the other group of chemoautotrophs, Thiobacillus spp. Because it is possible to have the same over-all base composition with entirely different base sequences (and thus with different genetic 'messages'), this method does not permit us to decide whether or not these chemoautotrophs are closely related genetically.

\section{CONCLUSIONS}

DNA base composition studies of species of the genus Thiobacillus have confirmed some of the similarities and differences previously indicated between the species in a numerical analysis (Hutchinson et al. 1965, 1966, 1967). The present work suggests a possible relationship between some members of the genus ( $T$. trautweinii, $T$. novellus, $T$. denitrificans and $T$. thioparus) and certain pseudomonads, e.g. Pseudomonas aeruginosa and $P$. fluorescens, which oxidize sulphur compounds. Although the base compositions of the chemoautotrophic nitrifying bacteria examined are in the range obtained with Thiobacillus species the method does not permit any conclusions about the relationship between them.

We are grateful to the Curator and Mr T. G. Mitchell of the Torrey Research Station, Aberdeen, for supplying authentic strains of bacteria and to Dr P. A. Trudinger (Baas-Becking Geobiological Laboratory, Canberra) and Dr M. I. H. Aleem (Research Institute for Advanced Studies, Baltimore, U.S.A.) for gifts of certain strains of Thiobacillus. The skilled technical assistance of Mr G. Megaw is gratefully acknowledged.

\section{REFERENCES}

Alexander, M. (1961). Introduction to Soil Microbiology. New York, N.Y., U.S.A.: Wiley and Sons. Anderson, J. R., Pramer, D. \& Davis, F. F. (1965). Nucleic acid composition of Nitrosomonas europaea. Biochim. Biophys. Acta 108, 155.

BaAlsRud, K. (1954). Physiology of Thiobacilli. In Autotrophic microorganisms. Symp. Soc. gen. Microbiol. 4, 54.

BeERs, R. J. \& LockHART, W. R. (1962). Experimental methods in computer taxonomy. J. gen. Microbiol. 28, 633.

BohaceK, J., Kocur, M. \& MARTinec, T. (I965). Deoxyribonucleic acid base composition and taxonomy of the genus Micrococcus. Publ Fac. Sci., Univ. J. E. Purkinye, Brno, K35, 318.

Dugan, P. R. \& LundgRen, D. G. (1965). Energy supply for the chemoautotroph Ferrobacillus ferrooxidans. J. Bact. 89, 825.

Hammerstein, E. (1924). Zur Kenntnis der biologischen Bedeutung der Nucleinsäureverbindungen. Biochem. Z. 144, 383.

HiLL, L. R. (1966). An index to deoxyribonucleic acid base compositions of bacterial species. J. gen. Microbiol. 44, 419.

Hutchinson, M., Johnstone, K. I. \& White, D. (1965). The taxonomy of certain thiobacilli. J. gen. Microbiol. 4I, 357.

Hutchinson, M., Johnstone, K. I. \& White, D. (I966). Taxonomy of the acidophilic thiobacilli. J. gen. Microbiol. 44, 373.

Hutchinson, M., JohNSTONE, K. I. \& White, D. (1967). Taxonomy of anaerobic thiobacilli. J. gen. Microbiol. 47, 17. 
Kay, E. M., Simmons, N. S. \& Downce, A. L. (1952). An improved preparation of sodium desoxyribonucleate. J. Am. chem. Soc. 74, 1724 .

Mandel, M. (1966). Deoxyribonucleic acid base composition in the genus Pseudomonas. J. gen. Microbiol. 43, 273.

Marmur, J. (196I). A procedure for the isolation of deoxyribonucleic acid from microorganisms. J. molec. Biol. 3, 208.

Marmur, J., Falkow, S. \& Mandel, M. (1963). New approaches to bacterial taxonomy. A. Rev. Microbiol. $\mathbf{1 7}, 329$.

Murray, R. G. E. (1963). The General Physiology of Cell Specialization, p. 28. London: McGraw-Hill.

Nicholas, D. J. D. \& Rao, P. S. (1964). The incorporation of labelled $\mathrm{CO}_{2}$ into cells and extracts of Nitrosomonas europaea. Biochim. Biophys. Acta 82, 394.

Schildkraut, C. L., Marmur, J. \& Doty, P. (1962). Determination of the base composition of deoxyribonucleic acid from its buoyant density in CsCl. J. molec. Biol. 4, 430.

SNEATH, P. H. A. (1957). The application of computers to taxonomy. J. gen. Microbiol. 17, 201.

STARKEY, R. L. (1935). Isolation of some bacteria which oxidize thiosulphate. Soil Sci. 39, I97.

Trudinger, P. A. (1967a). The metabolism of inorganic sulphur compounds by Thiobacilli. Rev. pure appl. Chem. 17, I.

Trudinger, P. A. $(1967 b)$. Metabolism of thiosulphate and tetrathionate by heterotrophic bacteria from soil. J. Bact. 93, 550.

Vishniac, W. \& SANTER, M. (1957). The Thiobacilli. Bact. Rev. 21, 195. 